\title{
Morphometric Analysis of the Menisci of the Knee Joint in South Indian Human Fetuses
}

\author{
Análisis Morfométrico de los Meniscos de la Rodilla en Fetos Humanos del Sur de India
}

"B. V. Murlimanju; ;*Narga Nair; **Shakuntala R. Pai; *Mangala M. Pai; ** Chandni Gupta; ${ }^{* * *}$ Vishal Kumar \& ${ }^{* * * *}$ Thejodhar Pulakunta

MURLIMANJU, B. V.; NAIR, N.; PAI, S. R.; PAI, M. M.; GUPTA, C.; KUMAR, V. \& PULAKUNTA, T. Morphometric analysis

of the menisci of the knee joint in south Indian human fetuses. Int. J. Morphol., 28(4):1167-1171, 2010.

SUMMARY: The morphometrical data related to the menisci of the adults have been reported by few authors and that of the fetuses have not been reported. The aims of the present study were to analyse the external circumference thickness, the width, peripheral and inner border lengths, and the distance between anterior and posterior horns of the fetal menisci and to compare the meniscal dimensions with that of the adult meniscal parameters which are available in the literature. The menisci from 106 knee joints of the formalin fixed South Indian fetuses which were obtained from the anatomy department were analysed. The fetuses which had musculoskeletal anomalies were excluded from the study. A vernier caliper of $0.02 \mathrm{~mm}$ accuracy and a non elastic cotton thread were used for the morphometry. After comparing the meniscal dimensions of the present study with the adult meniscus parameters, we established that the fetal parameters of the meniscus are entirely different from the adults. These differences are may be due to the mesenchymal differentiation or variability of the vasculature early in embryonic life. We believe that our study will provide support to the fetal anatomy, concerning surgical procedures and arthroscopy of the knee joint. Since the morphometric studies of the fetal menisci are not reported, this study may be considered new and needs to be studied further with different groups of fetuses from various stages of intrauterine development. This study is important not only for orthopedic surgeons, but also for morphologists and embryologists.

KEY WORDS: Morphometry; Knee joint; Menisci.

\section{INTRODUCTION}

Meniscal injuries in children and adolescents are being seen with increased frequency. The snapping knee syndrome is usually related with the type of the meniscus or to the presence of a tear of the meniscus. This syndrome appears more often in children and young adolescents (Kelly $\&$ Green, 2002). There are marked differences in the contour and insertion between the lateral and the medial menisci which are important in relation to the injury mechanisms (Smillie, 1975). Variations of form and in particular, the thickness and width of the menisci can determine the possibility and kind of injury (Almeida et al., 2004). But the data related to the morphometric parameters of these structures in the fetuses are not reported. So the aim of our study was to analyse the external circumference thickness, the width, peripheral and inner border lengths and the distance between anterior \& posterior horns of the fetal menisci and to compare the meniscal dimensions with that of adult meniscus parameters which are available in the literature.

\section{MATERIAL AND METHOD}

The embalmed human South Indian fetuses which were obtained from the anatomy department were used for the present study. The study included 106 knee joints (53 right \& 53 left sides) from 27 female and 26 male fetuses. The fetuses were preserved in $10 \%$ formaldehyde solution. The fetuses which had musculoskeletal anomalies were excluded from the study. The crown rump length of the fetuses ranged from $160 \mathrm{~mm}$ to $340 \mathrm{~mm}$. After the dissection

\footnotetext{
* Department of Anatomy, Centre for Basic Sciences, Kasturba Medical College, Manipal University, Mangalore, India.

** Department of Anatomy, Kasturba Medical College, Manipal University, Manipal, India

**** Department of Anatomy, K.M.C.T. Medical College, Calicut University, Calicut, India.

****** Department of Anatomical Sciences, St.Mathew's University School of Medicine, Grand Cayman Islands, British West Indies.
} 
of skin and muscles, the menisci were approached anteriorly by a longitudinal incision on each side of the joint capsule, cutting the patellar ligament and the collateral ligaments transversely. In order to expose the menisci clearly, the joint capsule and the intra articular ligaments were cut, and the condyles were circumferentially detached from their soft tissue attachments, exposing the tibial plateau. All dissections were performed in a systematic fashion and data were recorded on a standardized collection sheet.

The peripheral lengths of the menisci were measured with the nonelastic cotton thread. The thread was placed along the periphery of the meniscus and held in place with metallic pins. The length of this thread from the most anterior part of the insertional area to the most posterior part was measured and was called "peripheral length." In the same way, the inner free border length was measured by keeping the thread at the inner free edge (Fig. 1A).

Then the menisci were divided into 3 equal parts using the thread and the parts are called anterior, middle and posterior $1 / 3$ respectively (Fig. 1B). The width and thickness of the menisci were measured with the vernier caliper. The measurements of the thickness and width were done at the midpoint of the above mentioned 3 parts. The distance between the anterior and posterior horn was also measured. These parameters were used to determine dimensions of the menisci. Statistical analysis between the sides, genders and tibial plateau compartments were performed by using paired samples t-test, independent t-test and repeated measures anova. Two tailed $\mathrm{p}$-values $<0.05(\mathrm{a}=0.05)$ were considered significant. The SPSS 15.0 program was used for statistical analysis. Data were presented as mean \pm SD.

\section{RESULTS}

There were some statistically significant morphometrical differences found between the right and left side joints and also between the two sexes. The peripheral $\&$ inner border lengths of medial meniscus (26.66 \pm 4.69 $\mathrm{mm}$ and $14.72 \pm 2.63 \mathrm{~mm}$ ) were significantly more than $(\mathrm{p}=0.00, \mathrm{p}=0.00)$ the lateral meniscus $(25.14 \pm 4.05 \mathrm{~mm} \&$ $12.59 \pm 3.22 \mathrm{~mm}$ ) (Table I). Related to the thickness of outer circumference of meniscus, the anterior third $(1.61 \pm 0.39$ $\mathrm{mm})$ of the medial meniscus was the thickest part $(\mathrm{p}=0.003$, $\mathrm{p}=0.003)$ compared to posterior $(1.48 \pm 0.36 \mathrm{~mm})$ and middle thirds $(1.47 \pm 0.35 \mathrm{~mm})$. There was no statistically significant difference found between the posterior and middle thirds $(\mathrm{p}=1)$. A difference statistically significant was not observed $(\mathrm{p}=0.36, \mathrm{p}=0.06, \mathrm{p}=0.66)$ among the anterior, middle and posterior thirds of lateral meniscus. Comparing the average values of medial meniscus with the values of lateral meniscus, the statistically significant difference $(p>0.05)$ was not observed relating to the thickness. The average thicknesses of the medial and lateral menisci were $1.52 \pm$ $0.37 \mathrm{~mm}$ and $1.53 \pm 0.38 \mathrm{~mm}$ respectively (Table II). The individual analysis of each meniscus showed that the posterior third $(3.28 \pm 0.62 \mathrm{~mm})$ was the widest part of the medial meniscus $(\mathrm{p}=0.00, \mathrm{p}=0.00)$ than the anterior $(2.94 \pm 0.61 \mathrm{~mm})$ and middle thirds $(2.88 \pm 0.61 \mathrm{~mm})$. There was no statistically significant difference found between the anterior and middle thirds $(\mathrm{p}=0.72)$ (Table III). In the lateral meniscus the middle third part $(3.53 \pm 0.75)$ was the widest $(\mathrm{p}=0.00, \mathrm{p}=0.008)$ compared to the posterior $(3.44 \pm 0.63$ $\mathrm{mm})$ and the anterior third parts $(3.26 \pm 0.60 \mathrm{~mm})$. There
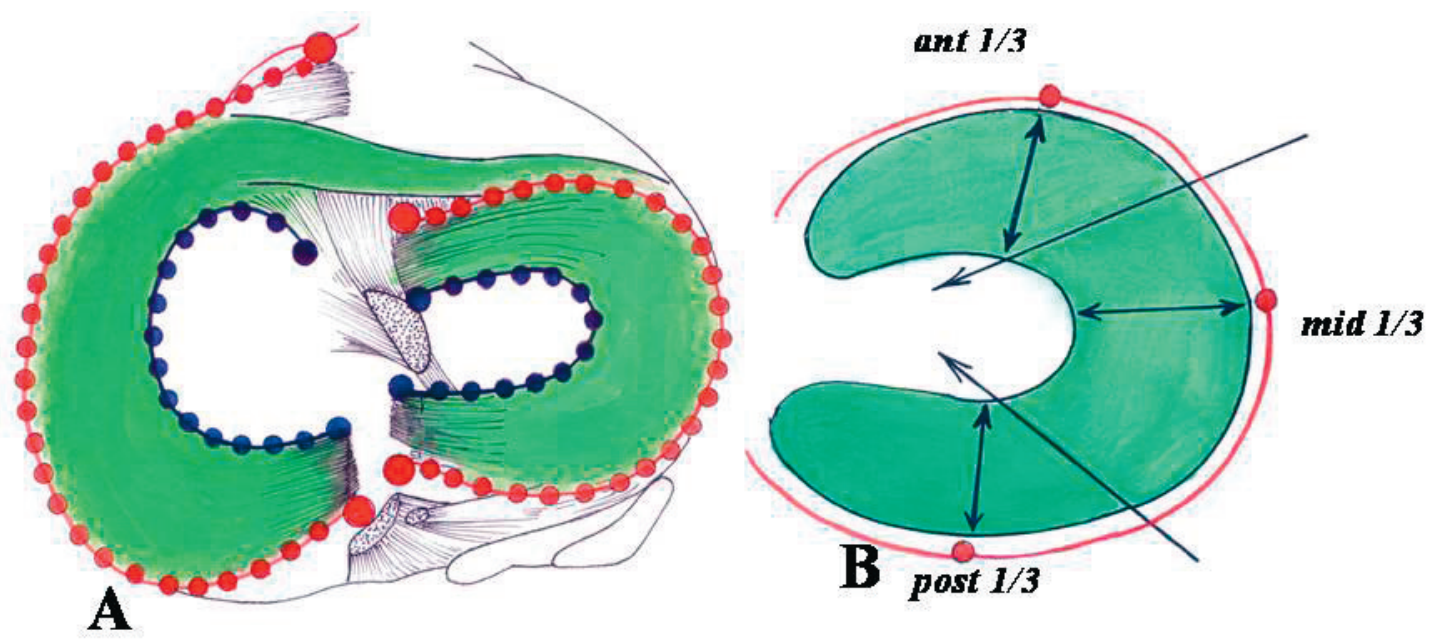

Fig. 1 A. Showing the method of measurements of the peripheral length \& inner border length of the meniscus along the dotted lines. B. Showing the diagram representing the three parts of morphometric analysis of the meniscus (the anterior, middle, and posterior thirds). 
was no statistically significant difference found between the anterior and posterior thirds $(\mathrm{p}=0.34)$. Comparing the average values of medial meniscus with the values of lateral meniscus, the lateral meniscus was wider than the medial meniscus $(\mathrm{p}<$ $0.05)$. The average width of the medial and lateral menisci was $3.04 \pm 0.62 \mathrm{~mm}$ and $3.41 \pm 0.66 \mathrm{~mm}$ respectively (Table III). The distance between the anterior and posterior horns of the medial meniscus $(3.79 \pm 0.89 \mathrm{~mm})$ was significantly more than $(\mathrm{p}=0.00)$ the lateral meniscus $(1.56 \pm 0.61 \mathrm{~mm})$.

Table I. Comparison of peripheral and inner margin lengths of fetal menisci ( $\mathrm{n}=212$ ).

\begin{tabular}{lcc}
\hline Length in mm & Medial meniscus & Lateral meniscus \\
\hline Peripheral length* & $26.66 \pm 4.69$ & $25.14 \pm 4.05$ \\
Inner Border length* & $14.72 \pm 2.63$ & $12.59 \pm 3.22$ \\
\hline
\end{tabular}

Values are mean $\pm \mathrm{sd}$, statistical significance (paired t-test) $* \mathrm{p}<0.05$.

Table II. Comparison of thickness of fetal menisci at different regions $(\mathrm{n}=212)$.

\begin{tabular}{lcc}
\hline Thickness in mm & Medial meniscus & Lateral meniscus \\
\hline Anterior 1/3 & $1.61 \pm 0.39 *$ & $1.57 \pm 0.41$ \\
Middle 1/3 & $1.47 \pm 0.35$ & $1.52 \pm 0.39$ \\
Posterior 1/3 & $1.48 \pm 0.36$ & $1.49 \pm 0.34$ \\
Average thickness & $1.52 \pm 0.37$ & $1.53 \pm 0.38$ \\
\hline
\end{tabular}

Values are mean $\pm \mathrm{sd}$, statistical significance (repeated measures anova) $* \mathrm{p}<0.05$

Table III. Comparison of width of fetal menisci at different regions ( $\mathrm{n}$ =212).

\begin{tabular}{lcc}
\hline Width in mm & Medial meniscus & Lateral meniscus \\
\hline Anterior $1 / 3^{*}$ & $2.94 \pm 0.61$ & $3.26 \pm 0.60$ \\
Middle $1 / 3^{*}$ & $2.88 \pm 0.61$ & $3.53 \pm 0.75^{*}$ \\
Posterior $1 / 3^{*}$ & $3.28 \pm 0.62 *$ & $3.44 \pm 0.63$ \\
Average width* & $3.04 \pm 0.62$ & $3.41 \pm 0.66$ \\
\hline
\end{tabular}

Values are mean $\pm \mathrm{sd}$, statistical significance (repeated measures anova) $* \mathrm{p}<0.05$

\section{DISCUSSION}

The data referring to the dimensions of the menisci are varied (Almeida et al.). Although the morphometric data related to the menisci of the adults have been reported by few authors (Testut \& Latarjet, 1975; Cailliet et al., 1976; Hayashi et al., 1988; Motta Filho et al., 1999; Almeida et al.), that of the fetuses have not been reported. In the present study, we determined that there were some statistically significant differences found between the right $\&$ left side joints and also between the two sexes, but these differences seem to be not significant clinically. Kohn \& Moreno (1995) reports that, if bony fixation of a meniscal substitute should be attempted, the entire circumferential length of the meniscus plus both the insertion ligaments must be known. This length in the adult menisci has been described previously by Kohn \& Moreno and McDermott et al. (2004). But the data of fetal meniscus about this parameter has not been reported before, here we report both the peripheral and inner border lengths. In the present study, the peripheral and inner border lengths were more in the medial meniscus than the lateral. In adult meniscus also, the same finding was reported by McDermott et al. Variations of form and in particular, thickness and width of the menisci can determine the possibility and the kind of injury. However, the data related to the morphometric parameters of these structures are scarce (Almeida et al., 2004). According to Rico \& Ayala (1997), in an arthroscopic revision carried out to determine the topographic location of meniscal ruptures, the middle third part of the medial meniscus is the region more frequently injured, followed by the posterior third. Related to the thickness of outer circumference of meniscus, we report the anterior third of the medial meniscus was the thickest part compared to posterior \& middle thirds and there was no statistically significant difference found between the posterior and middle thirds. In the adult meniscus study by Almeida et al., it was reported that there was no statistically significant difference observed between the three parts of the medial menisci related to the thickness. There was no statistically significant difference observed among the anterior, middle and posterior thirds of lateral meniscus relating to the thickness in the present study. Whereas Almeida et al. report that the middle third region of the lateral meniscus was the thickest in their specimens. Comparing the three parts of the medial meniscus with the lateral, the statistically significant difference was not observed in the present study relating to the thickness. According to Almeida et al., in the anterior and posterior third regions, the medial meniscus was the thickest.

In our specimens, the posterior third was the widest part of the medial meniscus than the anterior and middle thirds. There was no statistically significant difference found between the anterior and middle thirds. According to Almeida et al. also, the posterior third region was the widest followed by the middle third region and the anterior third region was the least. From our findings, the lateral meniscus was widest at the middle third region and there was no statistically significant difference found between the anterior and posterior thirds. In the study by Almeida et al. it was reported that there was no statistically significant difference found between the three regions of the lateral meniscus. In the present study, at all the three regions the lateral meniscus was wider than the medial meniscus. According to Almeida et al., the 
anterior one third region of the lateral meniscus was wider than the medial and the posterior third region was wider in the medial than lateral. In the middle third region there was no statistically significant difference found between the medial and lateral compartments. Miller (2003) reports that the medial meniscus is much larger in diameter, is thinner in its periphery and narrower in body. On the other hand, the medial meniscus is described by Didio (2002) showing the posterior region quite wide and an anterior extremity sharp and thin. Miller explained that the lateral meniscus is smaller in diameter, thicker at periphery, wider in body, and more mobile. The same author also explains that the radial tears occur most commonly in older patients at the midportion of the lateral meniscus. Figueroa et al. (1999) observed that the lateral meniscus is more variable in its general configuration than the medial meniscus, appearing frequently wider in the body. According to Smillie, the lateral meniscus shows a width higher and more uniform than the medial meniscus. However, Testut \& Latarjet and Didio mentioned that the medial meniscus is a little wider than the lateral meniscus. According to Miller, the most common type of tear in the menisci is the longitudinal tear, usually involving the posterior segment of either the medial or the lateral meniscus.

The width of the fetal menisci were previously measured by Kale et al. (2006) and from their study, the mean width of the midpoint of the anterior horn, posterior horn and the lateral side of the lateral menisci were recorded as $0.29,0.34$ and $0.37 \mathrm{~cm}$, respectively. The mean width of the midpoint of the anterior horn, posterior horn and the lateral side of the medial menisci were recorded as 0.28 , 0.29 and $0.26 \mathrm{~cm}$, respectively. These measurements are similar to our findings.

According to Smillie, the morphological differences of menisci, in particular, the thickness and width can determine not only the possibility of an injury, but also the location and the kind of injury. This author also suggests that the narrow meniscus is less prone to ruptures than the wide. This supposition is justified because the narrow meniscus is liable to a less action of femoral condyle. A higher evidence of this context is suggested by the rarity of injuries of the anterior third of medial menisci, as related by Rico \& Ayala.

According to Smillie and Farias Filho et al. (1985), the lateral meniscus covers a higher area of the tibial plateau, due to its semicircular format and the proximity between the insertions of its horns. In this study we established that the distance between the anterior and posterior horns of the medial meniscus was significantly more than the lateral meniscus. The same finding was reported in the adult meniscus study also. This finding gives an aspect in which the lateral meniscus shows the form of a ring almost complete. This high proximity between the insertions of its horns would be one of the reasons for the lateral meniscus to be less prone to lacerations (Kapandji, 1998; Miranda, 2000).

After comparing the meniscal dimensions of the present study with that of the adult meniscus parameters which are available in the literature, we established that the fetal parameters of the meniscus are entirely different from the adults. The lateral meniscus was wider than the medial in all the three regions. These differences may be due to the mesenchymal differentiation or variability of the vasculature early in embryonic life. This may be the reason for the higher incidence of the discoid lateral meniscus in the fetuses as reported by Kale et al.

The limitation of this study includes the simplistic technique of relying on linear measurement of a nonlinear structure. Implications for future study would involve studying the radius of curvature or measurement of volume of the meniscus with software like scion image analyzer. Since the detailed morphometric data on fetal anatomy was not reported, this study may be considered new and needs to be studied further with different groups of fetuses from various stages of intrauterine development. We believe that our study will provide support to the fetal anatomy, concerning the surgical procedures and arthroscopy of the knee joint. This study is important not only for orthopedic surgeons, but also for morphologists and embryologists.

MURLIMANJU, B. V.; NAIR, N.; PAI, S. R.; PAI, M. M.; GUPTA, C.; KUMAR, V. \& PULAKUNTA, T. Análisis morfométrico de los meniscos de la rodilla en fetos humanos del sur de India. Int. J. Morphol., 28(4):1167-1171, 2010.

RESUMEN: Los datos morfométricos relacionados con los meniscos de los adultos han sido reportados por algunos autores, mientras que en fetos éstos aún no han sido descritos. El objetivo del estudio fue analizar, en fetos, el grosor de la circunferencia externa, ancho, y longitud de los márgenes interno y externo, asi como la distancia entre los cuernos anteriores y posteriores. Además, comparar las dimensiones del menisco fetal con los parámetros de adultos disponibles en la literatura. Fueron analizados los meniscos de 106 articulaciones de rodillas fijadas en formalina, pertenecientes a fetos del sur de la India, obtenidos desde el Departamento de Anatomía. Los fetos con anomalías musculoesqueléticas fueron excluidos del estudio. Un pie de metro de $0,02 \mathrm{~mm}$ de precisión junto a hilo de algodón no elástico fueron utilizados para la morfometría. Después de comparar las dimensiones del menisco del presente estudio con los parámetros de meniscos adultos se estableció que los meniscos fetales son totalmente diferentes a los adultos. Estas diferencias pueden deberse a la diferenciación mesenquimal o la variabilidad de temprana 
vasculatura en la vida embrionaria. Creemos que nuestro estudio prestará apoyo a la anatomía fetal, en relación con los procedimientos quirúrgicos y la artroscopía de la rodilla. Los estudios morfométricos no han informado datos en meniscos fetales, por lo que esta investigación puede ser considerada novedosa y requiere seguir siendo estudiada con diferentes grupos de fetos en las diversas etapas del desarrollo intrauterino. Además el estudio de ser importante para los cirujanos ortopédicos, también lo es para morfólogos y embriólogos.

PALABRAS CLAVE: Morfometría; Articulación de la rodilla; Meniscos.

\section{REFERENCES}

Almeida, S. K. S.; Demoraes, A. S. R.; Tashiro, T.; Neves, S. E.; Toscano, A. E. \& Deabreu, R. R. M. Morphometric study of menisci of the knee joint. Int. J. Morphol., 22:181-4, 2004.

Cailliet, R. M. D. Sindromes Dolorosas. Joelho: dore incapacidade. Rio de Janeiro, Manole, 1976.

Didio, L. J. A. Tratado de Anatomia Aplicada. $2^{\mathrm{a}}$ ed. São Paulo, Atheneu, 2002.

Farias Filho, O. C.; Lyrio Mello, R. S.; Souza, D. C. \& Paz Júnior, A. C. Menisco discóide: estudo retrospectivo. Rev. Bras. Ortop., 20:106-10, 1985.

Figueroa, M.; Ríos, A. L. L.\& Narváez, C. Menisco discoide interno: presentación de un caso y revisión de la literatura. Rev. Colom. Ortop. Traumat., 3:155-8, 1999.

Hayashi, L. K.; Yamaga, H.; Ida, K. \& Miura, T. Arthroscopic meniscectomy for discoid lateral meniscus in children. J. Bone Joint Surgery, 70A:1495-500, 1988.

Kale, A.; Kopuz, C.; Edzer, M.; Aydin, M. E.; Dem¥r, M. \& Ynce, Y. Anatomic variations of the shape of the menisci: a neonatal cadaver study. Knee Surg. Sports Traumatol. Arthrosc., 14:975-81, 2006.

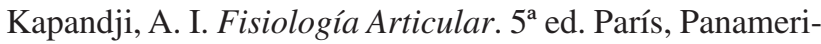
cana, 1998.

Kelly, B. T. \& Green, D. W. Discoid lateral meniscus in children. Curr. Opin. Pediatr., 14:54-61, 2002.

Kohn, D. \& Moreno, B. Meniscus insertion anatomy as a basis for meniscus replacement: a morphological cadaveric study. Arthroscopy, 11:96-103, 1995.
McDermott, I. D.; Sharifi, F.; Bull, A. M.; Gupte, C. M.; Thomas, R. W. \& Amis, A. A. An anatomical study of meniscal allograft sizing. Knee Surg. Sports Traumatol. Arthrosc., 12:130-5, 2004.

Miranda, E. Bases de Anatomia e Cinesiologia. Rio de Janeiro, Sprint, 2000.

Motta Filho, L. A. J.; Motta, L. A. J. \& Mota Filho, G. R. Menisco lateral discóide: correlação anátomo-clínica. Rev. Bras. Ortop., 34:457-60, 1999.

Rico, E. G. C. \& Ayala, C. E. A. Localización de las rupturas meniscales en nuestro medio. Rev. Mex. Ortop. Traumatol., 11:10-3, 1997.

Miller, R. H. III. Knee injuries. In: Canale, S. T. \& Beatty, J. H. (Eds.). Campbell's Operative Orthopaedics. Philadelphia, Mosby Elsevier, 2003. pp.2182-99.

Smillie, I. S. Injuries of the knee Joint. $4^{\mathrm{a}}$ ed. London, Living Stone, 1975.

Testut, L. \& Latarjet, A. Tratado de Anatomía Humana. $10^{\mathrm{a}}$ ed. Barcelona, Salvat, 1975.

\section{Correspondence to: \\ Dr. Murlimanju B. V. \\ Assistant Professor, Department of Anatomy \\ Kasturba Medical College, Manipal University \\ Mangalore - INDIA}

Telephone: 918242211746

Telefax: 918242421283

Email:drmanju_22@rediffmail.com flutesnowmm@gmail.com

Received:28-01-2010

Accepted:19-08-2010 
